\title{
In Vitro Effects of Biomaterials on Mesenchymal Stem Cells Viability and Proliferation
}

\author{
GABRIELA TANASIE $1,5 \#$, FLORINA BO IN ${ }^{2,5 \#, ~ R O M U L U S ~ F A B I A N ~ T A T U " \#, ~ A L I N A ~ M A R I A ~ S I S U 4 \#, ~ M I R A B E L A ~ C R I S T E A 5, ~}$ \\ DANIELA ANCA PUSCASIU ${ }^{*}$, EMANUEL ADELIN NEMES ${ }^{1}$, CARMEN SOFICA TATU ${ }^{1,5}$ \\ ${ }^{1}$ Victor Babes University of Medicine and Pharmacy Timisoara, Functional Sciences Department, Physiology Discipline, 2 \\ Eftimie Murgu Sq., 300041, Timisoara, Romania \\ ${ }^{2}$ Victor Babes University of Medicine and Pharmacy Timisoara, Functional Sciences Department, Immunology Discipline, 2 \\ Eftimie Murgu Sq., 300041, Timisoara, Romania \\ ${ }^{3}$ Victor Babes University of Medicine and Pharmacy, Timisoara, Ortopaedics-Traumatology-Urology and Imagistic Department, \\ Ortopaedics-Traumatology III Discipline, 2 Eftimie Murgu Sq., 300041, Timisoara, Romania \\ ${ }^{4}$ Victor Babes University of Medicine and Pharmacy Timisoara, Anatomy and Embryology Department, 2 Eftimie Murgu Sq., \\ 300041, Timisoara, Romania \\ ${ }^{5}$ OncoGen Centre, 300041, 10 losif Bulbuca Blvd., 300736, Timisoara, Romania \\ Victor Babes University of Medicine and Pharmacy Timisoara, Microscopic Morphology Department, Cellular and Molecular \\ Biology Discipline, 2 Eftimie Murgu Sq., 300041, Timisoara, Romania
}

\begin{abstract}
Mesenchymal stem cells (MSCS) are increasingly being used in regenerative medicine to repair various tissue types. This study aimed to assess changes in MSCs properties as a result of their interaction with two biomaterials in order to evaluate their in vitro compatibility. We have used two types of biomaterials, as follows: hydroxyapatite anodized titanium (HA-Ti) is used in bone reconstruction; it is hard and remains in the body, while patches of collagen combined with poly-e-caprolactone (C-PCL) are utilized in the reconstruction of soft tissue (particularly the skin); these patches resorb in the body, being only a temporary matrix that fosters and accelerates tissue formation. We have chosen to assess changes in morphology, viability and proliferation of MSCs obtained by lipoaspirate, through direct contact with the biomaterial or in eluate. MSCs properties were assessed by optical microscopy, fluorescence microscopy after acridine orange/ethidium bromide (AO/EB) staining, and the MTT assay. After result interpretation, we gained an image of the cytotoxicity phenomenon seen during the experiment and were able to assess viability of cell in contact with the biomaterials used. HA-Ti shows better interaction with cells, which preserve their viability, and does not influence MSCs growth, proliferation or morphology. In contrast, cells on C-PCL matrix become small, spherical, were detached from the plate and had lower viability percentage.
\end{abstract}

Keywords: regenerative medicine, mesenchymal stem cells, biomaterials, titanium plates, collagen patches

Regenerative medicine is a multidisciplinary field aimed at developing new systems able to restore impaired or damaged organ and tissue functions. Recent developments in this field have led to revolutionary technologies focused on strategies that bring us closer to personalized medicine $[5,14,21,23]$. Synthesis of structures capable of replacing human tissues or even organs is of great interest today. These structures are based on two essential components: on one hand, biocompatible materials able to stimulate both survival and differentiation of populating cells; on the other hand, cells used in regenerative medicine. A large variety of human cells can be used: specifically differentiated adult cells deriving from the tissue to be replaced, various adult stem cell types, embryonic stem cells and pluripotent stem cells [10]. MSCs have been suggested to be a patient-specific drugstore. Availability and versatility of these remarkable cells make them an excellent choice of treatment for a wide range of clinical pathologies [1,7].

Biocompatible materials (scaffolds) are generally 3D microporous structures within which cells are able to grow generating new tissue $[19,20,22]$. A scaffold thus acts as a temporary basis for various cell populations aimed at tissue regeneration or repair. Accordingly to source and origin, the tissue substitutes are divided in: autogenous grafts, allografts, xenografts and alloplasts. The alloplast are synthetic graft material, which have only osteoconductive properties [8]. Various manufacturing techniques are currently used for scaffold synthesis, and recently developed 3D printing methods allow to adapt the synthetic matrix to the dimensions and complex composition of the replaced tissue [2].

The study of effects resulting from the contact between cells and biosynthesis materials is the first step in our understanding of biomaterials - human body interaction $[13,19,22]$. Recent research has shown the well-known fact that scaffold properties impact the cell structure, although the specific mechanisms through which biomaterials influence cell evolution are difficult to assess $[4,24]$.

\section{Experimental part}

Materials and methods

We have studied the effects of two biomaterials on mesenchymal stem cells through direct contact or by means of eluate.

\section{Cells}

We chose to test human mesenchymal stem cells obtained from lipoaspirate, which were previously isolated in our lab, then expanded up to the 8th passage and cryopreserved in liquid nitrogen. 
Thawing of cells kept in liquid nitrogen:

Cells removed from the liquid nitrogen container were rapidly thawed in water bath at $37^{\circ} \mathrm{C}$. Cells viability was then checked using Trypan Blue exclusion assay. At the end of procedure, we have put the cells on culture plates and placed them into an incubator at $37^{\circ} \mathrm{C}$ in $5 \% \mathrm{CO}_{2}$ atmosphere in order to expand them.

Biomaterials: We tested two types of biomaterials: one for the reconstruction of hard tissues (bone), plates of hydroxyapatite anodized titanium (HA-Ti) and the other for soft tissue reconstruction (skin), patches of collagen combined with poly-å-caprolactone (C-PCL), collagen: PCL ratio $=1: 2$.

\section{Preparation of biomaterials:}

Biomaterials were prepared as follows: squares with sides of $8-10 \mathrm{~mm}$ were extracted from the HA-Ti material and cylinder-shaped samples of $5 \mathrm{~mm}$ diameter and $2 \mathrm{~mm}$ height from the C-PCL materials. We used glass slides of $12 \mathrm{~mm}$ diameter as controls.

\section{Biomaterial sterilization:}

Titanium plates were sterilized by autoclaving because this procedure is not technically complicated, it is not time consuming and needs minimal equipment [13]. C-PCL patches were sterilized with ethylene oxide as this is an effective method and the procedure does notinterfere with material's surface finishing or with water solubility of materials [9].

\section{Preparation of samples for direct contact:}

Cells were seeded on 6 -well plates of $9.6 \mathrm{~cm}^{2}$, at a density of $10^{5}$ cells/well in human MSC-specific culture medium: DMEM (Dulbecco's Modified Eagle's Medium) (Gibco) + $10 \%$ fetal bovine serum (Sigma) $+1 \%$ Penicillin/ Streptomycin (Sigma) $+3 \mathrm{ng} / \mathrm{mL}$ bFGF (basic Fibroblast Growth Factor) (R\&D). Plates were left for $24 \mathrm{~h}$ into an incubator at $37^{\circ} \mathrm{C}$, in $5 \% \mathrm{CO}$ atmosphere in order to adhere to well. Materials to be tested were placed in the centre of each well, on top of adhered cells. Glass slides were placed in the control wells. The samples were incubated at $37^{\circ} \mathrm{C}$ in humid atmosphere with $5 \% \mathrm{CO}_{2}$ for 5 days and were checked daily by means of Nikon Elipse E600 invertedlight phase-contrast microscope. Images were acquired with a Nikon digital camera which was connected to the microscope. After 5 days, we examined the cells stained with acridine orange/ethidium bromide (AO/EB) by fluorescence microscopy.

Preparation of eluate-type samples:

Samples of the biomaterials described above were placed on culture plates $T 12.5 \mathrm{~cm}^{2}$ with specific MSC medium thoroughly covering the biomaterials. Samples were incubated at $37^{\circ} \mathrm{C}$ for 7 days. After biomaterial removal from the culture medium, as the matrix was disintegrated, we have centrifuged the eluate sample at $1000 \mathrm{rpm}$ for $10 \mathrm{~min}$ and kept the supernatant. Further, we incubated for $24 \mathrm{~h}$ a 6 -well plate of $9.6 \mathrm{~cm}^{2}$ seeded with
MSCs ( $10^{5}$ cells/well) in the culture medium previously described at $37^{\circ} \mathrm{C}$ in $5 \% \mathrm{CO}_{2}$ atmosphere. After $24 \mathrm{~h}$, we have replaced the culture medium with $3 \mathrm{ml}$ of the eluate acquired through the protocol we described above. We added culture medium without eluate as a positive control, and culture medium + 15\% DMSO as a negative control.

Samples incubated as previously described were checked on a daily basis by the inverted-light phase-contrast microscope, with the images acquired by the aid of a digital camera. At the end, after 5 days we examined the cells by fluorescence microscopy after staining with acridine orange/ethidium bromide (AO/EB), according to the protocol below.

Fluorescence microscopy after acridine orange/ethidium bromide (AO/EB) staining allows to visualize apoptosis related changes in cells and their nuclei in order to verify cell viability. Live cells appear green (with acridine orange), while apoptotic cells appear orange (with ethidium bromide).

We used the MTT assay [3-(4,5-dimethylthiazol-2-yl)2,5-diphenyltetrazolium bromide] to study cell viability, cytotoxicity and proliferation as it allows to assess the oxidative metabolism and the response of a cell population to external factors that may exert either a positive or a negative effect on cultured cells. Results were interpreted as absorbance difference between tested samples (mesenchymal stem cells in contact with material samples or eluate) and control cells (MSCs without contact with material or eluate), by applying the following formula:

$\% C=100 \times(1-[(O D$ sample + OD control $)-O D$ sample])/OD sample

\section{Results and discussions}

\section{Direct contact test - optical microscopy analysis}

After adding the tested material, we checked the distribution, proliferation and viability of mesenchymal stem cells with the inverted microscope on a daily basis. In case of control, cells have normal proliferative appearance, adhere to the well and grow nextto and under the glass slides at both 24 and $48 \mathrm{~h}$.

At 24 and $48 \mathrm{~h}$ from the contact with hydroxyapatite titanium, the cells had normal proliferative appearance, adhered to the well and grew next to the material margins without showing a tendency to colonize it.

Two hours after the contact with the C-PCL matrix, cells were adhered to the well and grew up to the material margins with no tendency to colonize it, although after 24 $h$ they started to detach from the plate, while the remaining cells were small and spherical.

\section{Eluate test - optical microscopy analysis}

At $24 \mathrm{~h}$ positive and negative control, cells have normal appearance. The $48 \mathrm{~h}$ positive control shows normal cell proliferation, as compared with the image acquired after $24 \mathrm{~h}$, when cells had normal appearance and were adhered to the well. Conversely, at the $48 \mathrm{~h}$ in negative control, no proliferation is seen and clearly affected lysed cells appear.

In contact with HA-Ti eluate, after $24 \mathrm{~h}$ the cells are adhered to the well and of normal appearance, while

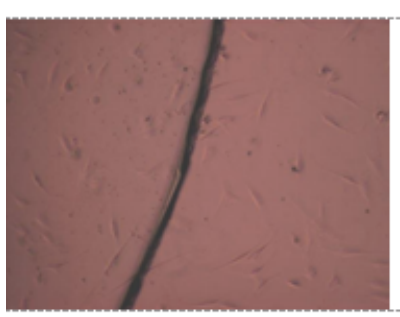

a

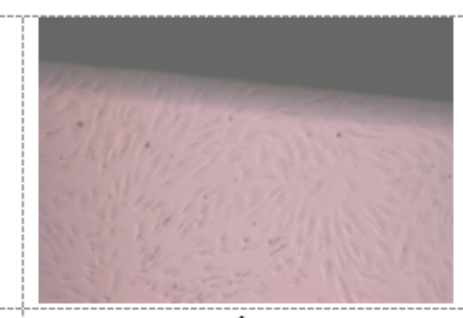

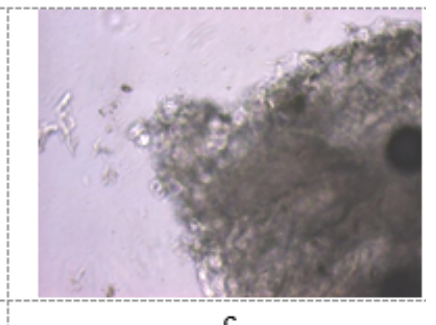

Fig. 1 Microphotographs (inverted light) of MSCs after 24h direct contact with biomaterials, ob. 10x (a - control, b - HA-Ti, c - C-PLC) 

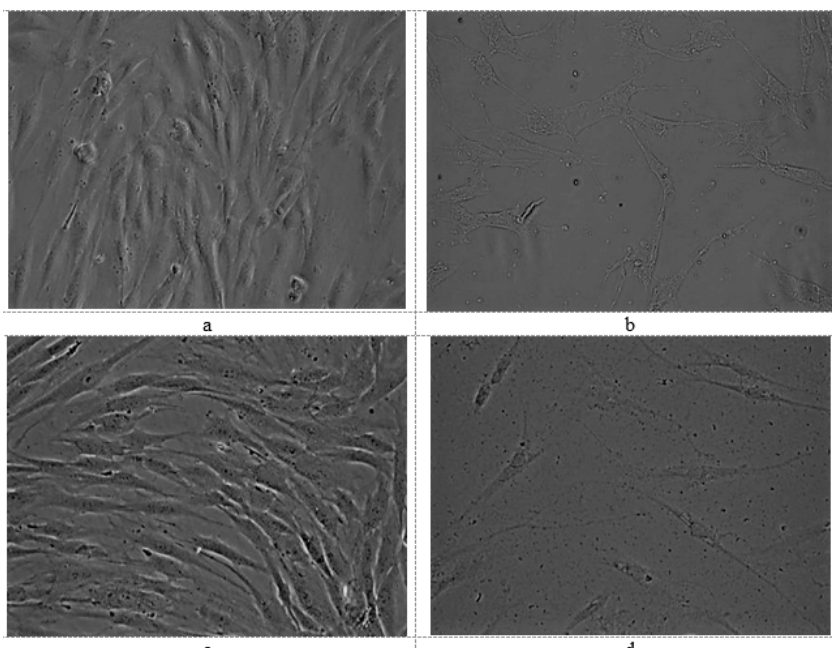

Fig. 2 Microphotographs (inverted light) of MSCs after 48h culture in eluate from biomaterials, ob. 10x. (a - positive control, $b$ - negative control, c- HA-Ti, d - C-PLC)

normal proliferation without affected cells, similar to the positive control, is seen after $48 \mathrm{~h}$.

After $24 \mathrm{~h}$ of contact with the C-PCL matrix, the normal appearance cells are adhered to the well, while affected cell proliferation, almost the same with the negative control is seen at $48 \mathrm{~h}$. These optical microscopy test results provide data on the cytotoxicity phenomenon seen during our experiment. By analyzing the images acquired during both test types, we observed that hydroxyapatite-coated titanium has no effect on cell growth, proliferation or morphology, similar to control cells. Conversely, the C-PCL matrix affects growth, proliferation and morphology of cells, which become small, spherical and detached from the plate.

\section{Direct contact test - AO/EB analysis}

We have seen in control samples that cells aligned towards the glass slides margins to which they adhered. Cells under the glass slide were affected, as were unable to grow as well as those at the glass slides margins.

In HA-Ti, at distance from sample, we saw the cells had no definite space orientation, while those at the plate margin exhibited a parallel orientation, with most of them being viable.

In C-PCL, at distance from matrix, cells are visibly affected however having quasi-normal appearance, while we saw fewer, pyknotic spherical small cells.

\section{Eluate test - AO/EB analysis}

Most of the positive control cells were viable, while the negative control cells were visibly affected.
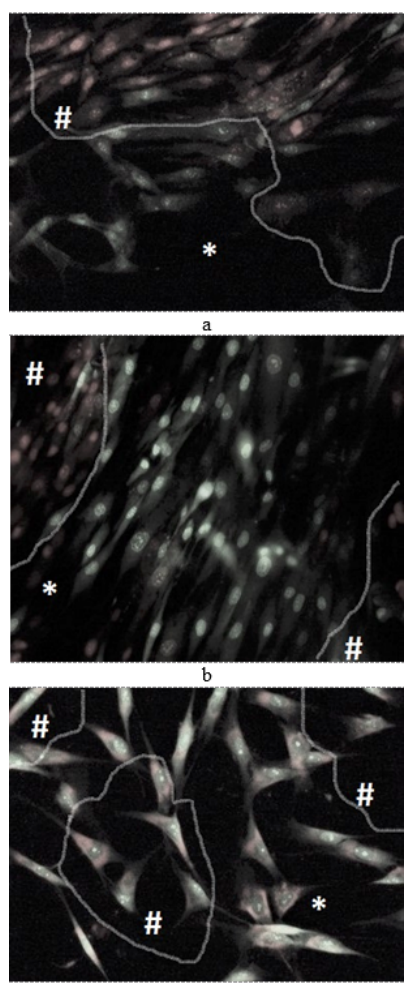

Fig. 3 Microphotographs (fluorescence) of MSCs in direct contact with biomaterials, ob. 10x, staining with acridin-orange/ ethidium-bromide (a - control, b - HA-Ti, c - C-PLC);

*area $=$ live cells, green fluorescence; \#area = dead/ apoptotic cells, orange fluorescence

Most of the cells in HA-Ti eluate were viable.

In C-PCL matrix eluate cells were visibly affected, both in appearance and proliferation, and similar to negative control cells.

\section{MTT test}

The MTT assay results plead for a better MSCs viability in contact with C-PCL samples, in comparison with $\mathrm{HA}-\mathrm{Ti}$ material. The obtained values are shown in table 1.

The vital AO/EB staining tests and the MTT assay allow for the assessment of cell viability in contact with the biomaterials. In case of C-PCL matrix, we observed that the greater the distance between cells and matrix on plate, the better the development and the greater the viability of cells. However, such a tendency was not seen in case of HA-Ti plates, with the cells growing and being viable both on the distance and near the material, as well as on its surface. Experiments using scanning electron microscopy concluded that differences in material structure and presence of surface irregularities may influence the effectiveness of matrix anchorage in the tissue [15]. In a study comparing the MSCs viability after seeding onto or inside of a combined C-PCL scaffold the results demonstrated that cell loading into collagen gels was as much as $50-60 \%$ more efficient than that of direct cell

\begin{tabular}{|c|c|c|}
\hline Biomaterial & Test type & Viable cells (\%) \\
\hline HA-Ti & Eluate & $79 \pm 9.07$ \\
\hline HA-Ti & Direct contact with material & $74.33 \pm 6.02$ \\
\hline C-PCL & Eluate & $89 \pm 5.29$ \\
\hline C-PCL & Direct contact with material & $87.33 \pm 5.03$ \\
\hline
\end{tabular}

Table 1

VIABILITY OF MSC AFTER EXPOSURE TO DIRECT CONTACT OR BIOMATERIAL'S ELUATE - MTT ASSAY

Fig. 4 Comparative results of MTT assay

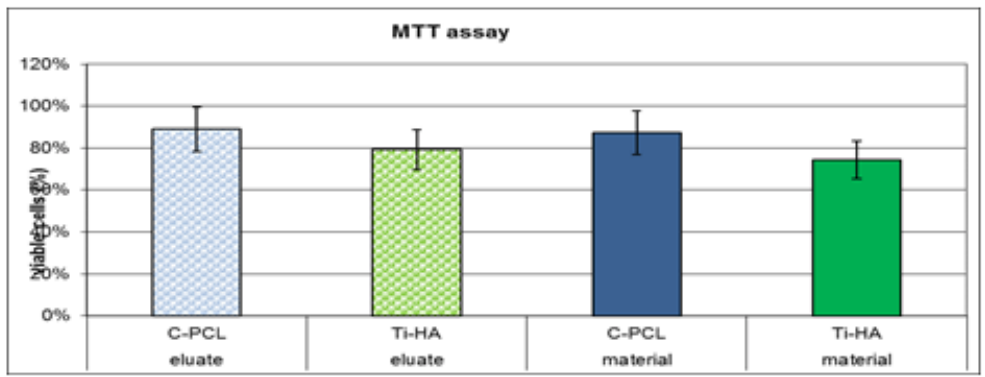

MATERIALE PLASTICE $\bullet 54$ No. $3 \bullet 2017 \quad$ http://www.revmaterialeplastice.ro 
seeding [18]. Studies on animal models shown that differences in bone formation depend on the biomaterial's capacity to select and guide MSCs behavior. In bone tissue engineering, scaffolds provide a mechanical and biochemical microenvironment for MSCs [6]. The MTT assay also enables the assessment of viability of cells in contact with studied biomaterials [16]. The cell viability percentage is lower for the C-PCL matrix in both eluate and direct contact tests. On the other hand, in both biomaterials type, the contact with eluate seems to be more aggressive for cells than direct contact. We can speculate that some substances with harmful effect on MSC s are released from biomaterials during the incubation with cell media.

The results we have obtained with the hydroxyapatite are similar to those reported in the literature, confirming the absence of cytotoxicity in direct contact with this material [3], which makes it an ideal candidate for orthopedic and dental implants [17, 12]. This study is only the preliminary one, so lot of other assays should be done for confirming the material's biocompatibility, including demonstration of absence of epigenetic toxicity and establishing the biomarkers for MSCs toxicity screening [11].

\section{Conclusions}

In vitro cultured mesenchymal stem cells in the presence of eluate and in direct contact with hydroxyapatite-coated titanium plates show no morphological alterations, while their growth and proliferation seem not to be altered. The same cell type in directcontact with collagen-polycaprolactone matrices are affected, become spherical, lose their adherence properties and show a great degree of apoptosis. Cytotoxicity assessed by MTT assays show cells in eluate samples had better viability than those in direct contact, while the hydroxyapatite-coated titanium alloy exerted lower cytotoxic effect on mesenchymal stem cells compared to the collagen-polycaprolactone matrices.

\section{References}

1.ALBERTS BRUCE et. al., Molecular biology of the cell. s.l.: Garland science, Taylor \& Francis Group, LLC, 2008. ISBN9 78-0-8153-4r05. 2.GABOR, A., HOSSZU, T., ZAHARIA, C., KOZMA, A., COJ OCARIU, A,C., NEGRUTIU, M.L., SZUHANEK, C., SINESCU, C., 3D Printing of a mandibular bone defect, Mat. Plast., 54, no. 1, 2017, p. 29

3.GAYATHRI V, HATIKRISHNAN V, MOHANAN PV, Integration of rabbit adipose derived mesenchymal stem cells to hydroxyapatite burr hole buton device for bone interface regeneration. International Journal of Biomaterials, 2016, 2016:1-9

4.JAKAB K, NEAGU A, MIRONOV V ET AL. Engineering biological structures of prescribed shape using self-assembling multicellular systems. The National Academy of Sciences, 2004, PNAS, Vol. 101. doi: 10.1073/pnas.0400164101.

5.MATA A, AZEVEDO HS, BOTTO L, GAVARA N, SU L, New Bioengineering Breakthroughs and Enabling Tools in Regenerative Medicine, Curr Stem Cell Rep (2017), 3:83-97, DOI 10.1007/s40778017-0081-9

6.MERBAKI M, COQUELIN L, LAYROLLE P, BATTAGLIA S, TOSSOU M, HERNIGOU P, ROUARD H, CHEVALLIER N, Enhanced human bone marrow mesenchymal stromal cell adhesion on scaffolds promotes cell survival and bone formation, Acta Biomaterialia, 2017 in press
7.MURPHY MB, MONCIVAIS K, CAPLAN A, Mesenchymal stem cells: environmentally responsive therapeutics for regenerative medicine, Experimental \& Molecular Medicine, 2013, 45, e54; doi:10.1038/ emm.2013.94

8.POPESCU,I E., AGOP, P., FORNA, D., EARAR, K., FORNA, N.C, Bone substitutes used in guided bone regeneration technique, Mat. Plast., 54, no. 2, 2017, p. 390

9.RAHAMAN MN, MAO JJ, Stem Cell-Based Composite Tissue Constructs for Regenerative Medicine, Biotechnology and Bioengineering, 2005; 91(3): 261-284

10.RAMAKRISHNA V, JANARDHAN PB, SUDARSANAREDDY L, Stem Cells and Regenerative Medicine - A Review. Annual Review \& Research in Biology, 2011; 1(4): 79-110

11.REMYA NS, SYAMA S, GAYATHRI V, VARMA HK, MOHANAN PV, An in vitro study of the interaction of hydroxyapatite nanoparticles and bone marrow mesenchymal stem cells for assessing the toxicological behavior, Colloid and Surfaces B: Biointerfaces, 2014, 117:389-397

12.SZUHANEK C, PARASCHIVESCU E, GADEA E, SISU AM, et al. Cephalometric investigation of Class III dentoalveolar malocclusion, Romanian Journal Of Morphology and Embryology, 2011, 52(4): 13431346

13.TATU, R.F., IVASCHESCU, V., HURMUZ, M., TATU, C., PUSCASIU, D., SISU, A., Vibration Behaviour of Bone Fractures Fixed with Biocompatible Material Plates, Mat. Plast., 50, no. 4, 2013,p. 269 14.TATU, R.F., MARSAVINA, L., VOICONI, T., HURMUZ, M., TATU, C., UNGUREAN, C., ROSU, S., Reinforcement of Tibial Fixation in Anterior Cruciate Ligament Reconstruction Using a Polyester Multi Stranded Long Chain Polyethylene Core Suture Material, Mat. Plast., 51, no. 4, ,2014, p. 460

15.VLASA, A., BIRIS, C., LAZAR, L., BUD, A., BUD, E., MOLNAR VARLAM C, MARIS, M., PACURAR, M, Scanning electron microscope analysis of Titanium alloy orthodontic implants, Mat. Plast., 54, no. 2, 2017, p. 345 16.WISE D, Biomaterials and Bioengineering Handbook sl: CRC Press, 2000, ISBN 978-0824703189

17.ZHOU H, LEE J, Nanoscale hydroxyapatite particles for bone tissue engineering, Acta Biomater, 2011; 7(7):2769-81. doi: 10.1016/ j.actbio.2011.03.019

18.YU H-S, WON J-E, JIN G-Z, KIM H-W, Construction of mesenchymal stem cell-containing collagen gel with a macrochanneled polycaprolactone scaffold and the flow perfusion culturing for bone tissue engineering, BioResearch Open Access, 2012, 1(3): 124-136

19.CRAINICEANU, Z., IANES, E., MATUSZ, P., BLOANCA, V.., SELEACU, E., NARAD, V.., NARAD, G., NODITI, G., BRATU, T., Method of Titanium Plate Use for Morphological and Functional Human Face Recontruction, Mat. Plast., 53, no. 3, 2016, p. 518

20.NODITI GH, TODEA, C.,Laser Doppler Imaging - as a Non-invasive Method for Assesing Regional Microcirculation when using Plastic Materials for Guided Healing, Mat. Plast., 50, no. 1, 2013, p. 40

21.GHIBAN, N., BORTUN, C.M., BORDEASU, I., GHIBAN, B., FAUR, N., CERNESCU, A., HANGANU, S.C., Evaluation of Mechanical Properties by Stereo-and Scanning Electron Microscopy of Some Heat Curing Dental Resins, Mat. Plast., 47, no. 2, 2010, p. 240

22.ROSU, S.,PETER F., TATU, R.F., ABS 3D Printed Facial Study Model Using Hermite Matrix Interpolation for Manufacturing Facial Epistasis, Mat. Plast., 51, no. 3, 2014, p. 290

23.CAPLESCU, C.R., MARSAVINA, L., BORDEASU, I., SEKEI, R., The fracture of polyurethane materials in the presence of stress concentrators, Mat. Plast., 47, no.3, 2009, p.379

24.NODITI, GH., LEDETI, I., SIMU, G., SUTA, MM. L., ONETIU, D., FULIAS, A.., Microwave - assisted synthesis of local anesthetic procaine from benzocaine Rev. Chim. (Bucharest), 65, no.1, 2014, p. 65

Manuscript received: 13.07 .2017 